This item was submitted to Loughborough's Research Repository by the author.

Items in Figshare are protected by copyright, with all rights reserved, unless otherwise indicated.

\title{
The role of dedicated freighter aircraft in the provision of global airfreight services
}

PLEASE CITE THE PUBLISHED VERSION

http://dx.doi.org/10.1016/j.jairtraman.2016.06.003

PUBLISHER

(C) Elsevier Ltd.

VERSION

AM (Accepted Manuscript)

\section{PUBLISHER STATEMENT}

This work is made available according to the conditions of the Creative Commons Attribution-NonCommercialNoDerivatives 4.0 International (CC BY-NC-ND 4.0) licence. Full details of this licence are available at: https://creativecommons.org/licenses/by-nc-nd/4.0/

\section{LICENCE}

CC BY-NC-ND 4.0

\section{REPOSITORY RECORD}

Budd, Lucy C.S., and Stephen G. Ison. 2019. "The Role of Dedicated Freighter Aircraft in the Provision of Global Airfreight Services”. figshare. https://hdl.handle.net/2134/22460. 


\title{
The role of dedicated freighter aircraft in the provision of global airfreight services
}

\begin{abstract}
In 2014, over 51 million tonnes of cargo, valued at over US\$6.8 trillion, was flown around the world. Approximately $56 \%$ of this total (by global revenue tonne kilometres (RTKs)) was flown on dedicated freighter aircraft which were either manufactured specifically for this purpose or converted from passenger use. The remaining 44\% (by total global RTK) travelled as belly-freight in the holds of passenger flights or on combi (combination) or QC (quick change) aircraft that can accommodate both passengers and freight. Although both sources of capacity offer the same basic service - the aerial carriage of time sensitive and/or high value-toweight goods - they exhibit different cost structures, operating characteristics and spatial patterns of demand and supply. Using empirical data on the contemporary scale and scope of global freighter operations, this paper examines the role of dedicated freighter aircraft in the provision of global airfreight services and identifies a range of exogenous and internal factors which may affect the demand and supply side characteristics of all-cargo air services in the future.
\end{abstract}

Keywords: airfreight, freighter aircraft, belly-freight, freight capacity, cargo airlines

\section{Introduction}

The provision of safe, efficient and affordable commercial air transport services is a key enabler and driver of international trade and globalisation (Bowen, 2013; Birtchnell et al, 2015). In 2014, over 3 billion passengers and over 51 million tonnes of high value-to-weight and/or perishable goods, including cut flowers, cool chain pharmaceutical products, humanitarian supplies, live animals and consumer electronics (on which see Bowen and Leinbach, 2009), valued at over US\$6.8 trillion, were flown around the world (IATA, 2015). Just over half (56\%) of the global revenue freight tonne kilometres was flown on dedicated freighter aircraft while the rest was transported in the holds of passenger flights or on combi or QC aircraft operated by passenger-cargo combination carriers (Boeing, 2014). Despite only accounting for $0.5 \%$ of total world trade by volume, the particular characteristics of air shipments means air freight accounts for $35 \%$ of total world trade by value and air freight underpins the supply chains of many of the world's leading companies (IATA, 2016). Indeed, so reliant has modern society become on networks of aerial just-in-time logistics that any disruption to normal air freight flows, such as that which resulted from the airspace closures which accompanied the eruption of Iceland's Eyjafallajokull volcano in 2010, has widespread social and economic impacts (Budd et al, 2011). 
In addition to its socio-economic significance for global society, air freight also represents an important revenue stream for airlines. In 2015, freight generated, on average, $9 \%$ of total airline revenues, over twice as much as that derived from first class products (IATA, 2015). For certain carriers, freight's revenue contribution is significantly higher. $25 \%$ of Hong-Kong based Cathay Pacific's revenues, for example, come from freight and the airline states that air freight demand enables it to offer both higher frequencies on certain services and serve routes that ordinarily would not be commercially viable based on passenger demand alone (Gangwani, 2015). However, despite its commercial importance to contemporary airline (and, increasingly, airport) operations, air freight was originally considered to be a byproduct of passenger services and it was not until the latter half of the twentieth century that dedicated freight-only airlines and specialist airfreight services began to emerge.

Over the last 10 years, regulatory reform combined with weakening global demand, fuel price volatility, increased competition and a growing trend towards on-shoring production have conspired to depress cargo yields and cause commercial airlines to re-evaluate the nature of the freight services they offer. The challenging commercial environment confronting airfreight providers has been further exacerbated by overcapacity in the sector (which has, in part, been caused by the introduction of new passenger aircraft that have higher belly hold capacities), modal shift towards cheaper sea shipping, and an increase in international trade protection measures which are restricting cross border trade (IATA, 2016). In response, a number of passenger-cargo combination carriers and specialist airfreight operators have redeployed, reduced or entirely eliminated their freighter aircraft leading some industry commentators to question the long-term viability of maindeck (i.e. dedicated) cargo aircraft (Woods, 2015). However, despite these challenges, dedicated freighters offer both shippers and airlines a number of strategic commercial advantages. According to Airbus (2015), these include: greater control over schedules, volumes and routes; access to airports that are not usually served by passenger flights; and the ability to transport hazardous and outsized loads that cannot be accommodated as belly-freight.

Unlike existing literature which focuses on the airfreight sector as a whole (Morrell 2011; Kupfer et al, 2011) or the role of bellyfreight (Merkert and Ploix, 2014) this paper examines the role of dedicated freighter aircraft in the provision of global airfreight services. As such, the research builds on the work of Kupfer et al (2016), who studied the factors influencing airport choice for all-cargo aircraft operators in Europe, to examine the role of freight aircraft worldwide. In order to detail the demand for, the contemporary scale and scope of, and the likely future role of freighter role of freighters, the paper is structured into five sections. Following this introduction, section two describes the changing patterns of demand for, and subsequent evolution in the supply of, global airfreight services. Particular attention 
is afforded to the role of dedicated freighter aircraft and the factors that drive their use. Section three presents empirical data that has been obtained from surveys of global freighter registrations and industry data to detail the contemporary scale and scope of freighter operations worldwide. The fourth section examines the growth potential and challenges facing operators of dedicated freighter aircraft in the period up to 2030 before the conclusions are presented in section five.

\section{The development of global airfreight services}

The origins of international airfreight date back to the late-1920s when pioneering European airlines began transporting airmail and urgent diplomatic and valuable freight consignments, at marginal cost, between Europe and their respective nations' overseas colonies, dominions and mandates (Budd and Ison, 2015). To protect the interests of cargo consignees and determine air carrier liability in the event of loss or damage, Section III Article 5 of the 1929 Warsaw Convention obliged consignors to complete an 'air consignment note' (later an airway bill) which detailed the date, the origin and destination, personal details of the consignee, and the nature, weight, dimensions and quantity of the goods to be transported (Warsaw Convention, 1929).

After World War Two, in an attempt to protect fledgling air freight operators from destructive competition, the US Civil Aeronautics Board (CAB) prohibited passenger airlines from pricing belly-freight below the cost of carrying it in dedicated freighters (Miller 1973). This approach was adopted because it was believed that the 'maximum development' of the US air cargo industry required 'the operation of allcargo aircraft whose costs must be met' (CAB, 1968 p5). This intervention denied US belly-freight its cost advantages and encouraged both the expansion of all-cargo operators and the use of dedicated freighter aircraft by passenger airlines.

From the mid-1960s onwards, dedicated freighter aircraft were principally deployed on the world's major trading routes which linked the manufacturing economies of Asia with growing consumer markets of Europe and North America. These aircraft transported high value-to-weight perishable commodities, including consumer electronics, precision engineered components, fast fashion items, perishable foodstuffs and temperature-sensitive pharmaceutical products, further and faster than could be achieved by road, rail or sea, at higher volumes than that offered by belly-freight and at times and between airports that passenger flights did not routinely serve. As freight consignments were not subordinate to passengers' luggage, the use of freighter aircraft also offered cargo consignors better flown as booked performance, guaranteed capacity, access to a wider range of airports, greater control over routings and timings, and the ability to transport outsized, irregular, hazardous or specialist consignments which could not be transported as belly-freight (Crabtree, 2014). However, the high(er) operating costs of flying freighters as opposed to bellyfreight, which had been recognised by the US CAB in 
the late 1940s, resulted in airfreight being 4-5 times more expensive than road transport and 12-16 times more expensive than transporting it by sea with airfreight rates typically ranging from $\$ 1.50-\$ 4.50$ per kilogramme (World Bank, 2016).

Nevertheless, the monetary value of airfreight goods combined with the time savings afforded by transporting products by air meant that airfreight came to represent an attractive option for companies who need to transport high value to weight and/or time sensitive commodities over long distances.

A key commercial challenge facing freighter operators was (and remains) not an absence of demand but the uneven spatial nature of it. Unlike demand for passenger services, which is usually bi-directional, the consequence of moving goods from their site of manufacture to their point of consumption almost inevitably means freight flows are unpaired and unbalanced. In order to address this lack of bi-directionality (also known as the 'backhaul problem') and avoid the need to fly empty sectors or sectors with low loads, most freighter aircraft are scheduled to perform triangular or multi-sector (and often intercontinental) routes which incorporate multiple airports in the course of a trip. While this promotes higher loads it also increases trip durations and may not be suitable for conveying certain types of perishable or time critical commodities.

The introduction of wide-bodied jet aircraft in the 1970s presented new opportunities and challenges to airlines. The Boeing 747-100, which entered service in 1970, could transport over 100 tonnes of belly cargo in addition to 300 passengers and their luggage. A freight-only version of the airframe, the B747F, which had a payload of over 120 tonnes and a capacity of almost 25,000 cubic feet, was introduced in 1972 (IAL Cargo, 2015). This was followed by the B747-200F, which was offered with an optional hinged nose door loading system to facilitate faster turnarounds and accommodate outsized loads, and the B747 combi (combination) which held both passengers and cargo on the main deck. The B747 combi was specifically designed to serve long and lean passenger routes that exhibited a higher-than-average demand for freight than passengers (examples of which included KLM's services between Amsterdam and the Caribbean).

The introduction of additional belly-freight capacity that was provided by the growing fleet of wide-bodied passenger jets created a capacity surplus which could be sold at marginal cost (Jensen 2012). The by-product nature of the space and the increasingly liberalised pricing policies that were introduced after the deregulation of the US airline industry in 1978 meant that belly-hold capacity could be sold more cheaply than the space on dedicated freighters as a large proportion of the flight's direct operating costs could be allocated to passenger services meaning the incremental costs of transporting belly-freight were limited to specialist handling, additional fuel, sales, and administration. As a result, belly-freight can, under certain operating conditions and parameters, charge a lower rate and still generate a profit of $30 \%$ or more (Conway, 2013). 
One consequence of this cost and price disparity between the two sources of airfreight capacity was that a number of passenger-cargo combination carriers, including American Airlines, Pan Am, TWA and United, left the dedicated freighter market. Their withdrawal coincided with the emergence and rapid expansion of a new type of integrated cargo-only operator that provides direct, often overnight, doorto-door delivery services using fleets of dedicated aircraft, trucks and courier vehicles (see Chan and Ponder, 1979). This structural realignment has meant that commercial freight capacity on dedicated freighter aircraft is now being provided by three different types of airline (Table 1).

Table 1: Commercial operators of freight-only aircraft (Note that this table intentionally excludes non-airline operators such as aircraft leasing companies and the military).

\begin{tabular}{lll}
\hline $\begin{array}{l}\text { Type of } \\
\text { operator }\end{array}$ & Principal operating characteristics & Examples \\
\hline $\begin{array}{lll}\text { Combination } \\
\text { carrier }\end{array}$ & - Carries passengers and cargo & \\
& - Flies cargo as belly-freight or on freighters & Lufthansa Cargo, \\
& - Operates point-to-point services or feeds & Emirates \\
& freight through hubs & SkyCargo, Turkish \\
& - May have lower marginal costs than & Airlines Cargo, \\
& integrators & Singapore Airlines \\
& - Provide direct door-to-door collection and & Cargo \\
\hline Integrated & Felivery services using a fleet of aircraft and & DHL \\
carrier & road vehicles & \\
& - Freight typically routed through key hubs such, \\
& as Memphis and Louisville (US) & \\
\hline Cargo-only & - Operate contract services or provide & Kalitta Air, \\
operator & guaranteed space for third party operators & Southern Air, Air \\
& - May operate specialist or outsized aircraft & Bridge Cargo, \\
& such as the An-124 or B747-8F & Cargolux, Volga \\
& & Dnepr \\
\hline
\end{tabular}

\subsection{Types of freighter aircraft}

As the market for airfreight evolved from the 1960s onwards so too did the aircraft that were used. Unlike passengers, who have to be transported on the main or upper deck of an aircraft specially configured for that purpose, airfreight can be carried in different ways. These include being flown on dedicated freight-only (freighter) aircraft, being transported as belly-freight in the holds of passenger aircraft, being loaded in combi (combination) aircraft that are permanently configured to carry both passengers and cargo on the main deck or in QC (quick change) aircraft that can be rapidly converted between passenger and cargo configuration on account of palletised seats, moveable partitions and easy-to-load pallets. Although these different sources of freight capacity offer the same basic service they exhibit different cost structures, operating characteristics and spatial patterns of supply and demand 
and the decision to fly freight on dedicated freighters as opposed to belly-freight is a commercial decision based on considerations of cost, convenience, reliability, the commercial value of the shipment and required levels of service as well as variables including an airline's market share and market power.

Unlike passenger airframes, dedicated freighters can either be manufactured from new or be converted from passenger use. Passenger-to-freighter (P2F) conversion usually occurs to older and less efficient airframes that have been withdrawn from passenger service. P2F conversion requires a number of structural modifications to be made to the airframe. These include main deck and bulkhead strengthening, the installation of new ventilation and fire detection and suppression systems, the removal of main deck passenger windows, fitting pallet handling and cargo restraint systems and creating large side cargo doors in the side of the fuselage to facilitate main deck loading. Owing to the complexity of the procedure, P2F conversions can only be undertaken by a limited number of licensed companies worldwide.

As well as originating from different sources, the diversity of the freight market means there is a need for many different types of freighter aircraft. These range in size from the B747-8F, a four engine jet aircraft with a range of $8,185 \mathrm{~km}$ and a payload capacity of 140 metric tonnes (Cargolux, 2015), to the twin turboprop Cessna Super Cargomaster EX with a range of $1,685 \mathrm{~km}$ and a payload of just over 1.8 tonnes (Cessna, 2015) and also include specialist freighters such as Airbus's Belugas, a fleet of specially converted A300s that transport outsize wing sections and large airframe subassemblies between the company's manufacturing plants.

\subsection{The effects of the 2008 recession and recent trends in freighter operations}

The last decade has witnessed significant changes in the freighter market. The 2008-09 recession, volatile fuel prices (which reached US $\$ 100$ a barrel at the height of the recession in 2008-09 before falling to US\$40 in 2015), political instability in the Middle East and the introduction of new environmental targets changed patterns of consumer demand and eroded profit margins in the traditional airfreight markets of Europe, North America and the Asian 'Tiger economies' of the Pacific Rim.

Since 2005, Northwest Airlines (of the US) and Japan Air Lines have both withdrawn their 12 strong B747F fleets. In Europe, the Air France-KLM-Martinair Cargo group progressively reduced its widebody freighter fleet from 26 aircraft in 2005 to 14 in 2013 to 5 by the end of 2016 (Conway, 2013; Air France KLM, 2014). In December 2011, Jade Cargo, a joint venture between Lufthansa Cargo and China's Shenzhen Airlines left the market. In January 2014, IAG Cargo (the parent company of British Airways, Iberia, Aer Lingus and Vueling) terminated its deal to lease three B747-8Fs from Global Supply Systems and exited the freighter business (Air Cargo News, 2014) while in March 2015 Thai Airways also ended its freighter operation to concentrate on belly-freight (Air Cargo News, 2015). 
Since 2008, over 500 freighters have been scrapped and over 350 placed into storage (Morris, 2013). 70 wide-bodied freighters were withdrawn from service in 2013-14 alone and only 55 orders for new builds were placed (ACMG, 2015). In part, this low demand for new freighters is due to the fact that average freighter load factors are only around $46 \%$ compared with around $80 \%$ for passengers (Gangwani, 2015).

Although such structural realignment, rates of airframe retirement and low load factors appear to indicate a challenging future for freighter operations, the global pattern is far more complicated than one of simple contraction. Demand for dedicated freighter services is actually growing in some world regions despite the introduction of more marginal bellyhold capacity, indicating that a much more complex change in freighter provision is occurring.

According to Boeing (2015), freighters still carry $80 \%$ of the airfreight conveyed between Asia and North America, 72\% of the air cargo between Europa and Asia and $43 \%$ of the air cargo between Europe and North America. Although many of the traditional airfreight markets in Europe, North America and parts of east Asia are stagnant or exhibiting only modest growth, demand is increasing in the emerging economies of the Near and Middle East. The cargo subsidiaries of Turkish Airlines, Etihad, Emirates and Qatar Airways are exploiting new growth opportunities and taking advantage of their country's strategic geographic location to feed and de-feed belly-hold and freighter consignments through their rapidly expanding and unconstrained hubs in Istanbul, Abu Dhabi, Dubai, and Doha (Conway, 2013). Airbus (2015) anticipate that the majority of the 800 additional new freighter aircraft that will be required over next 20 years will serve these emerging markets while the market for new airframes in Europe and North America will largely be a replacement one. In the period 2015 to 2034, Airbus (2015) anticipate that the number of dedicated freighters will increase from 1,633 to 2,867, slightly higher than Boeing's (2015) estimate of 2,730 units by 2033 .

\section{The scale and scope of contemporary freighter operations}

In order to appreciate the scale and scope of global freighter operations it is necessary to know the number of airframes and airframe types involved. This immediately presents a challenge of data quality and data comparability. Many of the potential sources of data are produced for commercial purposes and are not freely available while others lack transparency in terms of the data gathering and screening processes employed in their collection. A further issue relates to whether the airframes are airworthy and 'active' (i.e. actively accumulating flying hours in any given month), parked awaiting maintenance, stored for possible future return to service or permanently withdrawn from use. In order to ascertain an approximate figure, data was obtained from a number of sources including industry reports, 
airframe manufacturer data and industry press releases. These collectively suggest an in-service active global freighter fleet of between 1,623 and 1,633 aircraft in 2014 (see Flightglobal, 2014, Airbus, 2015).

By Spring 2015, this number had risen to 1,762. 34 different types of freighter were noted which were in operation with almost 200 different airlines worldwide (Table 2). Of these, the largest 33 carriers operated $70 \%$ of the world's freighter fleet and flew at least 10 airframes while the remaining $30 \%$ of freighters were operated by almost 170 different carriers (ACMG, 2015). These figures the market is dominated by a small number of carriers who operate the majority of the world's freighter fleet. Significantly, however, there are many airlines who operate just one or two aircraft and so do not have the economies of scale and scope of the largest operators. The data also indicates that there has been a consolidation in the sector. Between December 2012 and December 2015 the number of airlines who operate freighters declined from 202 to 129 (data derived from Freighters World, 2012 and 2015) and, in common with the passenger side of the business, the intervening three years were punctuated by bankruptcies, take overs and mergers.

Table 2: Operational freighter aircraft by category, 2015.

\begin{tabular}{lccl}
\hline Category & $\begin{array}{c}\text { Number of aircraft } \\
\text { within this category }\end{array}$ & $\begin{array}{c}\text { Number of aircraft } \\
\text { types }\end{array}$ & In service with* \\
\hline Wide-body jets & 978 & 18 & 85 airlines \\
Narrow-body jets & 601 & 10 & 109 airlines \\
Turboprops & 183 & 6 & 36 airlines \\
\hline
\end{tabular}

Data derived from: Harris (2014, 2015a, 2015b).

* Note that one airline may operate two or more categories of aircraft

Of the total global freighter fleet, $90 \%$ (1,579 units) were jets and 10\% (183 units) were turboprops (Figure 1). The jets, which have a longer range and higher cargo capacity, are typically deployed on long-haul high-yielding sectors between key cities and airport hubs while the turboprops are used to feed and de-feed capacity from the hubs. This 'build and break' capability is one of the key commercial advantages of operating freighters through a central hub as smaller consignments from multiple origins can be flown in on smaller aircraft, offloaded and then consolidated onto long haul flights for onward distribution or offloaded from inbound long-haul services before being split up and dispatched to their final destination on regional flights. 
Figure 1: Percentage of world freighter fleet by type, 2015.

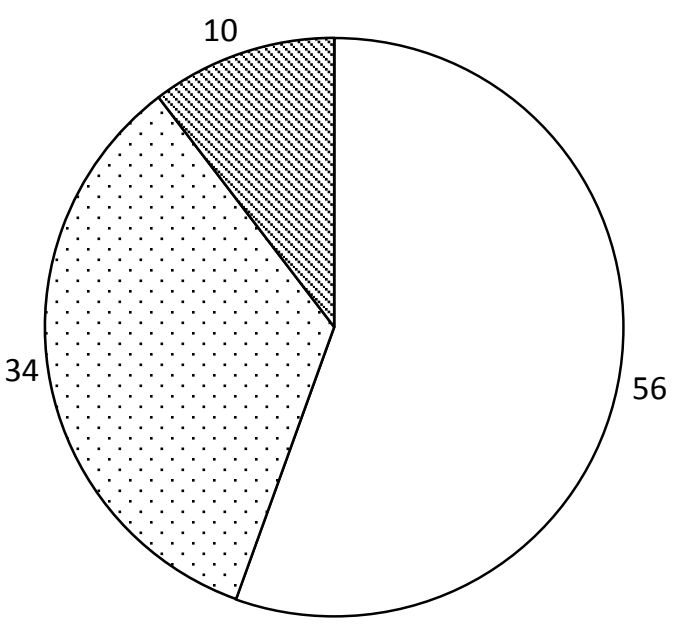

$\square$ Widebody jet aircraft

$\square$ Narrowbody jet aircraft

\$ Turboprop aircraft

Data derived from: Harris (2014, 2015a, 2015b).

Of the 1,597 jet freighters in service, 978 (62\%) were wide-bodies. These included 18 different types of aircraft, of which the B747F family was the most common with 266 units (Figure 2).

Figure 2: Global wide-body freighters by aircraft type, 2015.

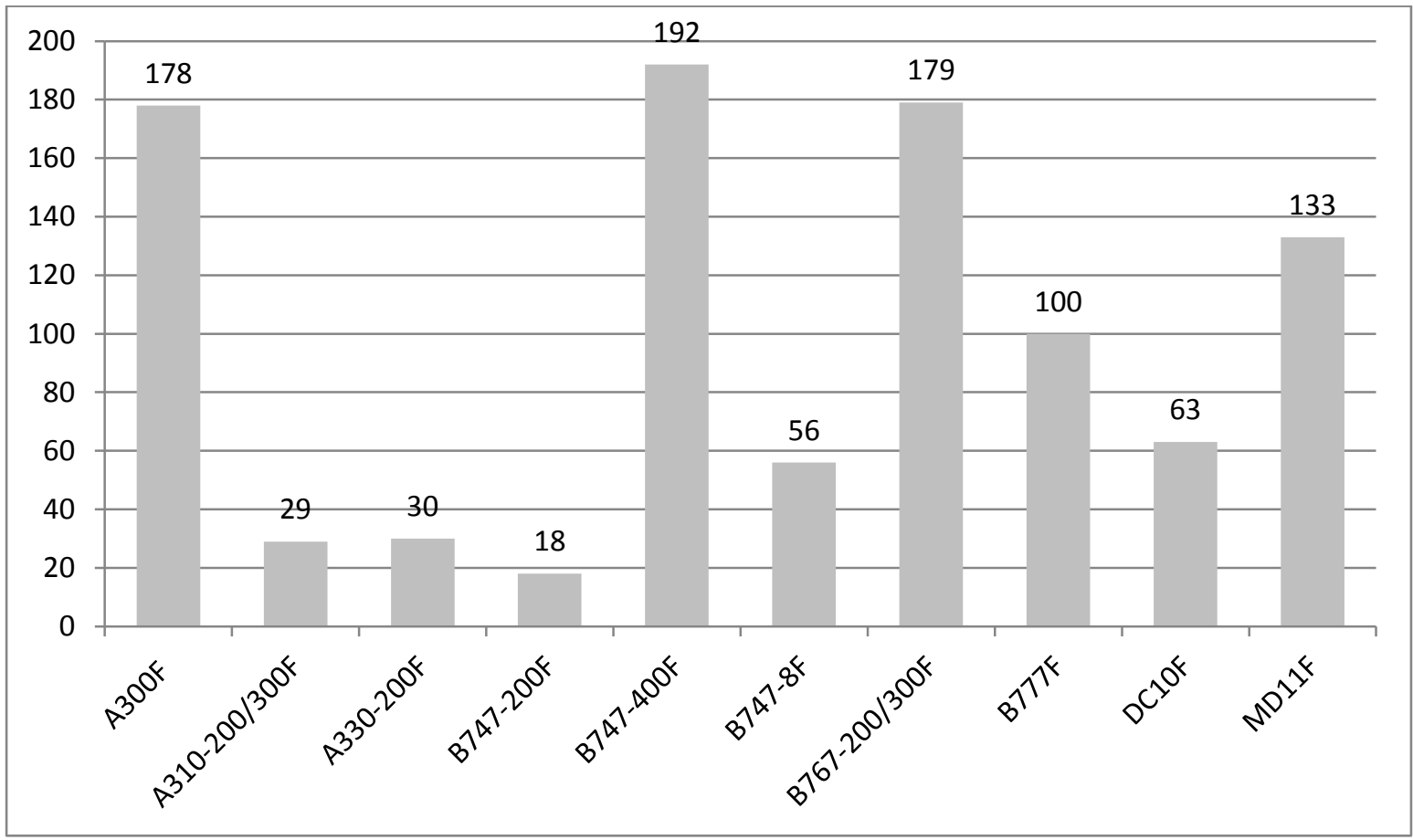

Source: Data derived from Harris (2015a). 
There were also 601 narrow-body freighters (representing $28 \%$ of the jet total) of 10 different types in service with 109 carriers (Figure 3). This represented an increase of 48 units on the same time in 2014. As with the wide-body jets, a small number of operators flew the majority of aircraft. 12 carriers had 10 or more narrow-body freighters in their fleet. 56 airlines operated 3 or more narrow-body aircraft while 53 flew fewer than 3 (Harris 2015b).

The most popular narrow-body freighters were the B757F (256 units) and B737F (239 units). The B757F is the most popular freighter of any category in the world with 256 units in service. The majority of B757Fs are flown by the major US integrators FedEx (104) and UPS (75). However, despite the B757's current popularity the B727F remains the most popular freighter ever, in part, due to its excellent short field performance, range and payload. Despite the age, relative fuel inefficiency and noise footprint of the B727F, 65 units remain in service.

Figure 3: The world's narrow-body freighter fleet by aircraft type, 2015

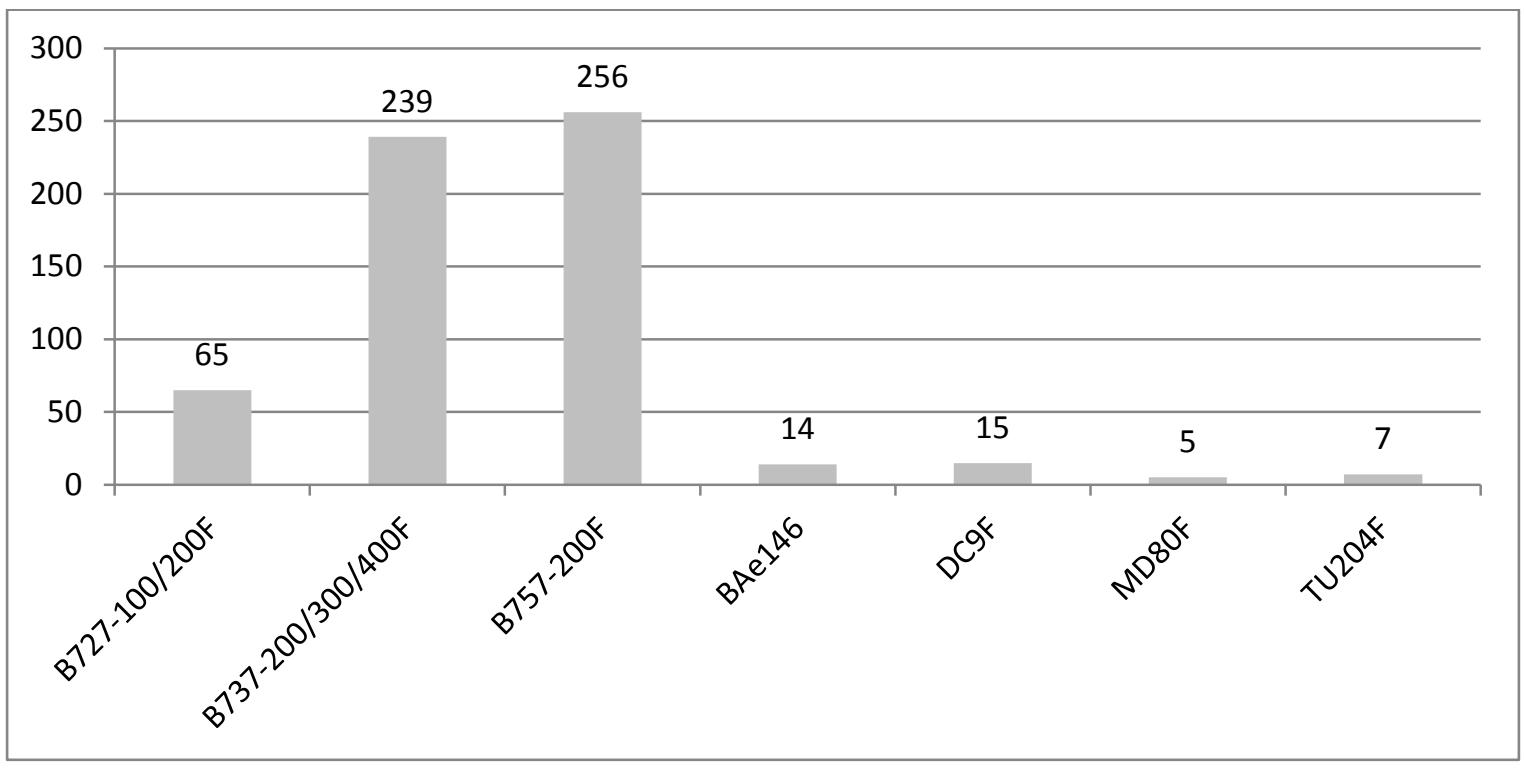

Source: Data derived from Harris (2015b)

The final category is turboprop freighters, of which 183 units comprising 6 types (see Table 3) were in service with 36 airlines. Interestingly, the spatial distribution of turboprops is different from that of the jets. Of the 183 in service, $61 \%$ (111 units) are operated by European carriers, many of which are under contract to integrators or national postal services (Harris, 2014). 28\% (51 units) are operated in the US and Canada (mainly as feeders for FedEx) while the remaining 10\% are flown in the rest of the world (with 8 units in Asia Pacific, 7 in Africa and 5 in Central and Latin America). 
Table 3: Turboprop freighter performance characteristics

\begin{tabular}{lcc}
\hline Airframe & Max payload (tonnes) & Number in service \\
\hline ATR42F & 5.6 & 43 \\
ATR72F & 8.4 & 49 \\
ATPF & 8.3 & 35 \\
F50 & 7.7 & 13 \\
Saab340F & 3.8 & 36 \\
Q400F & 8.8 & 3 \\
\hline
\end{tabular}

Source: Data derived from Harris (2014)

\subsection{The second hand freighter market}

Since the global recession of 2008 demand volatility has led to an increased number of freighter aircraft being temporarily or permanently withdrawn from use (ACMG, 2015). Converted and older aircraft are usually the first to be withdrawn and/or replaced as airlines seek to remove the least efficient assets from operational fleets. Morris (2013) calculated that only $36 \%$ of the freighter aircraft that were operational in 2000 were still flying in 2012 and, over that period, 975 airframes were permanently withdrawn from use or placed into storage while 1,225 (comprising 362 new builds and 863 P2F conversions) entered service.

Data shows that passenger-cargo combination carriers are aspiring to fleet commonality between their passenger and freighter fleets. The withdrawal of Thai Airways' B747-400 passenger fleet, for example, was quickly followed by the withdrawal of their B747-400Fs. Many withdrawn airframes are advertised for sale on the second hand market. Of the 900 aircraft listed on the Airfax database on 20 November 2015, 132 were freighters. The 24 different types available ranged from B747-400Fs and MD11Fs to Saab340Fs. These included both elderly and relatively new aircraft - the oldest freighter advertised for sale was manufactured in 1954 while the most recent was manufactured in 1998.

\section{The future for freighters}

Despite concerns over the current levels of (over)supply, the airfreight sector is predicted to grow anywhere between 4.1\% and 4.7\% a year between 2015 and 2034 (see Table 4). As a result, the number of in-service freighters may increase to as many as 2,930 units by 2034 (Table 4). Barrault (2015) estimates that the market for new build freighters will be worth in the region of US $\$ 210$ billion and that the majority of the new aircraft will be required to serve emerging airfreight markets. 
Table 4: Comparing future freighter demand to 2034

\begin{tabular}{llll}
\hline Source & $\begin{array}{l}\text { Current freighter } \\
\text { total (2014/15) }\end{array}$ & $\begin{array}{l}\text { Future number of } \\
\text { freighters (in 2034) }\end{array}$ & $\begin{array}{l}\text { Predicted annual } \\
\text { growth rate in } \\
\text { global air freight } \\
\text { demand }\end{array}$ \\
\hline $\begin{array}{l}\text { Airbus Global } \\
\text { Market Forecast } \\
(2015)\end{array}$ & $1,633(2014)$ & 2,687 & $4.4 \%$ \\
$\begin{array}{l}\text { Boeing Current } \\
\text { Market Outlook } \\
\text { report (2015) }\end{array}$ & $1,720(2014)$ & 2,930 & $4.7 \%$ \\
$\begin{array}{l}\text { ACMG 20 year } \\
\text { freighter forecast } \\
\text { (2015) }\end{array}$ & $1,609(2015)$ & 2,887 & $4.5 \%$ \\
$\begin{array}{l}\text { IATA Air Cargo } \\
\text { Strategy (2015) }\end{array}$ & Not stated & Not stated & $4.1 \%$ \\
\hline
\end{tabular}

However, despite predicted growth in the number of freighters, increased belly capacity in passenger aircraft means that the proportion of cargo transported in freighters is expected to fall. The B777-300ER, for example, can transport 22-25 tonnes of bellyhold freight in addition to its passenger load and so can facilitate more capacity at marginal pricing (Morris, 2013). Barrault (2015), for example, calculates that for every five new long haul passenger aircraft delivered, one fewer 100 tonne freighter is needed. As such, freighter operators face a significant challenge in that marginal capacity is growing at the same time as demand in key markets is weakening.

Another challenge facing freighter operators is the introduction of strict environmental standards relating to emissions and noise. Already, a number of major airports operate noise curfews and impose additional landing charges on operators of noisy and more polluting airframes. Although maintaining and operating older, less fuel efficient airframes, is less of an issue when oil is cheap, ultimately market based measures (including noise levies and associated operating charges) are likely to become increasingly important in determining the use of efficient aircraft and incentivising operators to re-equip their fleets with more modern aircraft. Already, the use of noise based landing charges and the introduction of fines for breaching prescribed noise thresholds has led operators to withdraw older aircraft from their fleet.

The effect of fuel prices in determining air freight demand could be seen during the period of high fuel prices in 2008/9. This had the effect of temporarily leading to a rise in slow shipping and a shift to slower but cheaper land and sea transport (IATA, 
2015). The effect of this modal substitution was most notable at the lower end of the market.

Further challenges facing freighter operators concern security, geopolitical tension and the trade protectionism. In 2010, explosive devices that had been concealed in printer cartridges and loaded into freighter aircraft were intercepted by security services at Dubai and East Midlands Airport. As a result, the security of the air cargo supply chain has come under increased scrutiny and countries, including the UK, have imposed much stricter security measures which in some cases require $100 \%$ screening of air cargo (IATA, 2015). The introduction of these additional security measures increases costs and shipping times.

However, despite these challenges, there are many opportunities for airlines using freighter aircraft to consolidate and grow their dedicated freight operations. As has occurred with passenger services, contrived regulatory reform and, in particular, the granting of fifth freedom and cabotage rights for air cargo will help make the industry more competitive. Increased open skies between US and China, for example, will help to promote international air freight and trade between the two nations. Further opportunities are likely to result from changes in global trade protection measures. Since 2008 , the WTO estimate that 1,244 restrictive trade protection measures were introduced and that 962 remain in place (cited in IATA, 2015). The removal of these barriers as well as growth in emerging economies will change the future pattern of air freight supply and demand with freighters being (re)deployed accordingly.

The gradual reduction of foreign ownership restrictions will also be likely to change the market but, until such a time as these regulations are dissolved, there is the potential for airlines to form greater air cargo alliances. Such alliances would offer more extensive geographic coverage, enhanced cost savings for shippers and operators, more frequent flights, and enhanced feed and de-feed opportunities at hubs. It could be argued that the WOW Cargo and SkyTeam Cargo alliances may be at the forefront of a future trend.

A final opportunity relates to the widely-anticipated introduction of new aircraft technologies in the form of drones, UAVs and airships. Although the use of such equipment may ultimately erode the market share of traditional fixed-wing freighters once a number of proof of concept, regulatory and safety issues have been resolved, current operators of freighter aircraft are arguably well placed to exploit the market potential of these, and other, new technologies to develop new value-added products, services and capabilities.

Finally, although this paper has focused on freighter aircraft and their operators, it is important that the role of airports is acknowledged. In order to facilitate future demand and changing consumer requirements, airports must develop the capacity and flexibility to accommodate changing patterns, volumes and types of freight by adapting their business models offering innovative products to airlines and shippers 
that added value to the existing offer. Such services may include 24 operations, increased use of IT technology to track shipments and reroute them in case of disruption, permanent airport representation, enhanced security screening, capacity guarantees, loyalty programmes, capital investment in surface access, the provision of integrated air-road/rail links, and dedicated sales and marketing teams. Such services would help enhance the airport's appeal to cargo operators and help make cargo services more streamlined, operationally efficient and cost effective.

\section{Conclusion}

This paper has explored the role of dedicated freighter aircraft in the provision of global airfreight services. It has shown that airfreight is provided by two distinct sources of capacity and revealed that, at the time of writing, a fleet of over 1,600 freighter aircraft transport $56 \%$ of the world's total air cargo by RTK. Moreover, empirical evidence of recent airline behaviour has shown that many passenger-cargo airlines are redeploying, reducing or entirely eliminating their fleet to concentrate on belly hold freight that can be carried at marginal cost. The review of the literature revealed that the challenges to dedicated freighter operations include the lack of bidirectional demand (the back haul problem), the introduction of new passenger aircraft that have larger belly hold capacities, the imposition of new security directives, and a slowdown in consumer demand for airfreighted goods. In addition, the dedicated freighter market is affected by the factors that influence demand for all types of airfreight, namely global economic vitality, oil price volatility, security concerns, trade protection measures and the introduction of new environmental safeguards.

In comparing the market predictions of leading airframe manufacturers and industry bodies, the paper has determined that as many as 2,930 freighters will be in active service in 2034 and that demand for airfreight will grow between 4-5\% per year until 2034. The data shows that the majority of freighter aircraft are operated by a small number of carriers and that, over the last few years, the number of operators has fallen as a result of continued consolidation in the sector. In order to remain competitive, freighter operators will need to be innovative in their approach, add value to existing products and ensure that they offer a service that is not only tailored to the needs of their customers but that is responsive to their changing requirements. In a maturing market, opportunities for market entry are likely to be limited to bespoke or niche services and those that are serving new markets or using new technologies such as drones, UAVs or airships. The role of dedicated freighters in the provision of global airfreight services has historically been one of both continuity and change and current evidence indicates that these characteristics will continue to shape the role of freighter aircraft in the future. 


\section{Acknowledgements}

We would like to thank the editor and the two reviewers for their very helpful comments and suggestions on an earlier version of this paper.

\section{References}

ACMG (2015) Twenty-year freighter aircraft forecast 2015-2034 Air Cargo Management Group, Seattle.

Air Cargo News (2014) IAG Cargo exits freighter business Air Cargo News 18/1/2014 Retrieved from www.aircargonews.net/single-view/news/IAG-Cargo-exitsfreighter-business/ on 3/12/2015.

Air Cargo News (2015) Freighters to go as Thai takes a hard look at its fleet 24/3/2015 Retrieved from www.aircargonews.net/single-view/news/freighters-to-goas-Thai-takes-a-hard-look-at-its-fleet/ on 3/12/2015.

Air France KLM (2014) Air France-KLM continues to reduce its full-freighter operations Air France KLM Communique 4/9/2014 Retrieved from www.airfranceklm.com/sites/default/files/communiques/communique_cargo_eng.pdf on $3 / 12 / 2015$.

Airbus (2014) Global Market Forecast Flying on Demand 2014-2033 Airbus SAS, Toulouse.

Airbus (2015) Global Market Forecast Airbus SAS, Toulouse.

Airfax (2015) Jet Air Transport Aircraft Available Retrieved from www.airfax.aero/available.htm on 20/11/2015.

ATAG [Air Transport Action Group] (2014) Aviation Benefits Beyond Borders Available online at www.aviationbenefitsbeyondborders.org Last accessed $12 / 12 / 2015$

Barrault N (2015) Air cargo trends: A long term view through the Airbus 20 year forecast Paper presented at the $9^{\text {th }}$ World Cargo Symposium, Shanghai, 10-12 March 2015

Birtchnell T, Savitzky S and Urry J (2015) Moving cargos in Birtchnell T, Savitzky S and Urry J (Eds) Cargo Mobilities Moving materials in a global age New York, Routledge pp1-16

Boeing (2014) World Air Cargo Forecast 2014-2015 Seattle, Boeing Commercial Airplanes 
Boeing (2015) Current Market Outlook, 2015-2034 Seattle, Boeing Commercial Airplanes

Bowen J and Leinbach T R (209) Competitive advantage in Global Production Networks: Air freight services and the electronics industry in southeast Asia Economic Geography 82(2) pp147-166

Budd L and Ison S (2015) Air cargo mobilities: past, present and future in Birtchnell T, Savitzky S and Urry J (Eds) Cargo Mobilities Moving materials in a global age New York, Routledge pp163-179

Budd L, Griggs S, Howarth D and Ison S (2011) A fiasco of volcanic proportions? Eyjafallajokull and the closure of European airspace Mobilities 6(1) pp31-40.

Cargolux (2015) Boeing 747-8F Freighter specifications www.cargolux.com/ftp/Brochures/pdfs/Boeing747-8F.pdf Last accessed on 12/12/2015.

Cessna (2015) Cessna Super Cargomaster EX www.cessna.txtav.com/caravan/super-cargomaster-ex Last accessed 12/12/2015.

Chan Y and Ponder R J (1979) The small package airfreight industry in the United States: A review of the Federal Express experience Transportation Research Part A: General 13(4) pp221-229;

Conway P (2013) Analysis - Should airlines invest in full freighters? Flightglobal 20/3/2013 Retrieved from www.flightglobal.com/news/articles/analysis-shouldairlines-invest-in-full-freighters/ on 3/12/2015.

Crabtree T (2014) Getting the most out of the Air Cargo System Paper presented at the 2014 IATS Retrieved from www.icao.int/meetings/iats2014/documents/crabtreeboeing.pdf on 20/11/2015.

Flightglobal (2014) World Airliner Census Sutton, Flightglobal Insight

Gangwani K (2015) Freighter operators still confident despite belly hold cargo surge Air Cargo News 14/12/2015 p3

Harris D (2014) Demand for turboprop freighters stalls Cargo Facts 29/5/2014 Retrieved from www.cargofacts.com/demand-for-turboprop-freighters-stalls/ on 3/12/2015.

Harris D (2015a) Widebody freighter fleet analysis - Part II Cargo Facts 25/2/15 Retrieved from www.cargofacts.com/widebody-freigher-fleet-analysis-part-ii/ on 3/12/2015 
Harris D (2015b) The narrowbody freighter fleet - today and tomorrow Cargo Facts 14/10/2015 Retrieved from www.cargofacts.com/the-narrowdoy-freigher-fleet-todayand-tomorrow/ on 3/12/2015.

IAL Cargo (2015) Boeing 747-100/-200/-300/-400 Freighters Retrieved from www.ialcargo.com/specs/b747.pdf on 10/12/2015.

IATA (2015) Cargo strategy August 2015

www.iata.org/whatwedo/cargo/documents/cargo-strategy.pdf Last accessed 10/03/2016.

IATA (2016) The Value of Air Cargo Available online at www.iata.org/wahtwedo/cargo/sustainability/pages/benefits.aspx Last accessed $10 / 03 / 2016$

Jansen G-J (2012) In focus: Assessing the difference in profitability between freighter and belly cargo operations Flightglobal 21/9/2012 Retrieved from www.flightglobal.com/news/articles/in-focus-assessing-the-difference-in-profitabilitybetween-freighters-and-belly-hold-cargo-operations/ on 3/12/2015.

Kupfer F, Kessels R, Van de Voorde E and Verhetsel A (2016) The origin-destination airport choice for all-cargo aircraft operations in Europe Transportation Research Part E: Logistics and Transportation Review 87 pp53-74

Kupfer F, Meersman H, Onghena E and Van de Voorde E (2011) World air cargo and merchandise trade in Macario R and Van de Voorde $\mathrm{E}$ (Eds) Critical issues in air transport economics and business London, Routledge pp98-111

Merkert R and Ploix B (2014) The impact of terminal re-organisation on belly-hold freight operation chains at airports Journal of Air Transport Management 36 pp78-84.

Miller J C III (1973) The optimal pricing of freight in combination carriers Journal of Transport Economics and Policy September 1973 pp258-268.

Morrell P (2011) Moving boxes by air. The economics of international air cargo London, Routledge

Morris R (2013) Where next for freighter markets? Flightglobal 07/06/2013 Retrieved from www.flightglobal.com/news/articles/analysis-where-next-for-freighter-markets386860 on $20 / 11 / 2015$

United States Civil Aeronautics Board (CAB) (1968) An Introduction to Airfreight Rates Revised Washington D.C. Civil Aeronautics Board, November.

Warsaw Convention (1929) Convention for the Unification of Certain Rules Relating to International Carriage by Air, Signed at Warsaw on 12 October 1929 (Warsaw Convention) 
Woods R (2015) Destination unknown: What the future may hold for freighters Air Cargo World 09/11/2015 Retrieved from www.aircargoworld.com/destinationunknown-what-the-future-may-hold-for-freighters/ on 21/03/2016

World Bank (2016) Air Transport Available online at www.worldbank.org Last accessed 10/03/2016. 